\title{
Empowerment of Women through Dairy Cooperatives in Karnataka, India
}

\author{
L. Niketha ${ }^{1 *}$, Gopal Sankhala1, Kamta Prasad ${ }^{2}$ and Sanjeev Kumar ${ }^{1}$ \\ ${ }^{1}$ National Dairy Research Institute, Karnal, India \\ ${ }^{2}$ Scientist (SG), Indian Institute of Sugar Research, Lucknow, India \\ *Corresponding author
}

\begin{abstract}
A B S T R A C T
Women focused approach was advocated as a part of the strategy under which sufficient

Keywords

Women,

Empowerment,

Dairy co-operatives,

Psychological

empowerment,

Economic

empowerment.

Article Info

Accepted:

17 June 2017

Available Online:

10 July 2017 number of women dairy cooperative (WDC) societies was formed at village level with the point of view that WDC would provide a source of additional income and an organized platform to seek redress of personal, social and other grievances of women to empower them. To assess the women empowerment level through WDCs, the present study was conducted in Karnataka by selecting three districts by proportionate random sampling method. A total of 6 WDCs and 240 members of WDCs constituted the sample of study. Most of the respondents had medium level of social empowerment, cultural empowerment, psychological empowerment, economic empowerment, technological empowerment, while, most of them had low level of legal and political empowerment. Empowerment under psychological component was the strongest while under political it was found to be the weakest. Herd size, milk production, milk sale, income from dairying, social participation, training received and information seeking behaviour were found to be positively and highly significantly correlated with dairy women empowerment. It could be inferred from the regression model that social participation, training received and information seeking behaviour were playing a major role in empowering the women. The role played by WDC is much appreciated which can also be replicated in other parts of the country.
\end{abstract}

\section{Introduction}

"One motivation for women's empowerment is basic fairness and decency. Young girls should have the exact same opportunities that boys do to lead full and productive lives. ... the empowerment of women is smart economics."

Robert Zoellick, President of World Bank, Spring Meetings, April 2008.

Gandhi ji clearly pointed out that villages are the backbone of Indian economy. Similarly a study conducted in 2008 by Max New York
Life Insurance and the National Council for Applied Economic Research (NCAER) shows that 70 per cent, i.e., 732 million of Indian population thrives in villages. The total literacy rate of India is 74.00 per cent in which male holds the upper hand with 82.00 per cent literacy and female around 66.00 per cent (Census, GOI, 2011). In India, female headed rural households are about 14.90 per cent only and female agriculture holders are about 10.90 per cent (FAO, 2010). High rate of female foeticide, lower wages, malnutrition, low level of skills, and greater 
exposure to domestic violence and vulnerability to sexual crimes are some of the other dimensions of women's low status. Though Women are not only carriers of human race but civilisation and sustainable development resets on them. They are neglected in their day to day life. Their role is silently appreciated without economic recognition, regard and accountability. Therefore, empowerment of women is of the utmost importance. In this direction dairying plays an important role as the primary occupation in the village is agriculture supplemented with cattle rearing. The need to engage underutilized labour force and generates additional income, guided farmers to practice dairy farming as subsidiary occupation.

Dairying is an occupation that supports the livelihood of women, especially the rural poor women in India. Dairy cooperatives ensure inclusiveness and livelihoods for small holders, especially women (Anonymous, 2012). Dairying in India is a female dominated enterprise (Fulzele and Meena, 1995). It is established beyond doubt that women always participated in dairy and animal husbandry activities in addition to their daily household chores (Belurkar et al., 2003). Women play crucial and significant role in livestock rearing, but their contribution in livestock rearing has not been given the due place they deserve. They always remain invisible workers (Chayal et al., 2009). Most of the activities of dairy farm were carried out by women so they spent more time compared to men in dairy farming. Farm women spent about 294.34 minutes daily in different dairy farm activities (John and Thirunavukkarasu, 2002).

In present scenario dairy cooperatives have been considered as the most important measure for improvement in the marketing mechanism of milk in rural areas to increase producers' share in consumers' rupees to empower the rural masses especially women. Women focussed approach were advocated as a part of the strategy under which sufficient number of women dairy cooperatives societies was formed at village level with the point of view that Women Dairy Cooperatives (WDCs) would provide a source of additional income and an organised platform to seek personal, social and other grievances. The major emphasis in the WDCs is that the rural women will not only benefit economically through the project but possession and management of milch animals would enable them to learn by inferences and help in capacity building. However, up to what level these cooperatives were succeeded in achieving the goal of women empowerment needs to be analysed to modify and improve the women dairy cooperatives for better empowerment of women. Keeping in view the present study was conducted with an aim to assess the level of women empowerment through WDCs in Karnataka.

\section{Materials and Methods}

According to the classification given by Planning Commission, the state of Karnataka is divided into two agro climatic zones which include Zone X - Southern Plateau and Hills Region and Zone XII - West Coast Plains and Ghat Region. Both the zones were selected for the study to represent the entire state. Based upon proportionate random sampling technique, two districts namely; Davangere and Chitradurga were selected from Zone X and one district from Zone XII namely Shimoga was selected. Thus, a total of three districts were selected. From each district, one taluk which was having highest number of WDCs was selected purposively. Thus a total of three talukas were selected for carrying out the study. From each selected taluk, one WDC which was having highest number of members and one WDC which was having 
comparatively less number of members in the WDC were selected purposively. Thus, from each taluk two WDCs were selected on the basis of above criteria. A total of six WDCs from three taluks were constituted the sample size. From each selected WDC, forty members' women dairy farmers were selected randomly. Thus, a total of 240 respondents were selected.

\section{Results and Discussion}

\section{Distribution of the respondents according to different dimensions of empowerment}

The respondents were categorised into the low, medium and high categories of empowerment on the basis of cumulative square root frequency method.

\section{Social empowerment}

The results presented in table 1 enunciated the empowerment level of women under social dimension. It revealed that most $(37.50 \%)$ of the respondents had medium level of social empowerment, followed by 34.58 per cent and 27.92 per cent of the respondents had low and high level of social empowerment. It can be concluded that most of the respondents were either in the medium or low categories of social empowerment. This may be due to the infancy of the WDC because of that these could not generate the required impulse for empowerment. The results are in line with the findings of Kumari (2008).

Rural women had started involving themselves in business activities for which WDCs are providing the platform. Women are supplying milk to WDCs; at a common point, which in turn resulted in gathering, more interaction and participation. Respondents reported that due to this they came to know each other in village, unnecessary misunderstanding and conflicts were resolved. There was co-operation among the women and others villagers which led to the healthy environment of village as a whole. As a result of WDCs' activity, women had interaction with government officials which helped them in shedding off their hesitations. The successful running of dairy cooperatives by women helped to increase credibility of women among villagers and villages, it helped them in acquiring freedom of speech, mobility and involvement in decision making both in home and community as well. WDCs influenced various social issues and matters concerning women directly as well as indirectly. WDCs acted as a tool for overcoming the barriers of caste, class and power in comparison to earlier rural development programmes.

\section{Cultural empowerment}

It is evident from table 1 that 47.50 per cent of the respondents had medium level of cultural empowerment, whereas, 35.83 per cent and 16.67 per cent had high and low levels of cultural empowerment, respectively.

It can be concluded that due the activities of WDC a very less number of respondents could feel the low level of cultural empowerment which implies that WDCs are working in the right direction as most of the members are feeling culturally empowered. Due to the WDC activities, it helped them to break the barriers of society, participated in community as well as national festivals, interacted with people outside family for social causes.

\section{Psychological empowerment}

With regard to psychological empowerment 42.50 per cent of the respondents had medium level of psychological empowerment while, 36.67 per cent and 20.83 per cent of them had high and low levels of psychological 
empowerment. It can be inferred that most of the members were having either medium or high levels of empowerment. It shows that WDCs could make it possible to empower the women psychologically. Through participation in various activities women could break self-imposed, family and social barriers. WDCs influenced the women in increasing their self-confidence, being expressive to believe in self-abilities which resulted in courage to deal with social aspects, dealing with different institutions, people and take part in community activities which resulted in increased empowerment of women psychologically.

\section{Economic empowerment}

Economic empowerment of women is of paramount importance as from standard of living to status in the society are adjudged on the basis of money. Economic resource is an imperative for dignified sustainable wellbeing of human beings including women.

Regarding economic empowerment, 44.16 per cent of the respondents were in medium category and rests of the respondent belonged to the high $(35.84 \%)$ and low $(20.00 \%)$ level of economic empowerment categories. It can be inferred that 70 per cent of the respondents were economically empowered. The results are in line with Pandey (2005). Joshi (1996) revealed that economic empowerment of women is very important for raising their status in the society. Income from WDCs enabled the women to make most household expenditures without being dependent on their husbands (Sheela and Ramegowda, 2013). Putnam (2000) observed that SHGs, when combined with savings and credit, have enabled women to benefit economically by monetizing their contributions and the process empowered them to become change agent. Anuradha (2004) reported that regarding socio-economic extent of empowerment most of the respondents were empowered to a large extent for loaning procedure and process. WDCs were successful in empowering women economically as these have followed three pronged strategy; the members have been provided with soft loan to purchase the crossbred cow, the members have also been provided with assured marketing facilities in the vicinity of village and they have been provided with necessary technical know-how for proper management of the dairy animals.

WDCs have made positive impact particularly on well being of the weaker sections of the rural community through their re-distributive efforts of rural income in favour of them. Their activities resulted in increase in milk production, income, family assets, necessitated the opening of their personal account in bank, control on expenditure and savings of households giving women a suitable environment to experience their worth as a part of the society. Economic empowerment also boosted their confidence to express their power and rights.

\section{Political empowerment}

It can be observed that most of the respondents had low $(42.50 \%)$ level of political empowerment which was followed by medium $(35.42 \%)$ and high $(22.08 \%)$ levels of political empowerment (Table 1). As for as political empowerment is concerned it was found to be at the lower side; it might be due to the non-preference of the members for the political arena. Further, women's traditional role prevents them from participating in political related activities. The findings are similar with the results of Kumari (2008) and Pandey (2005).

The political empowerment aspect of the white revolution deals with connecting poor people with the government (Sheela and Ramegowda, 2013). Women in many parts of 
India do not have the same freedom of movement as men. Two-thirds of women in India face restrictions in visiting public places, such as market, health care centre or other communities, by their own (Kishor and Gupta, 2009). As a consequence their participation in public life and in local political bodies is limited. Bhagyalakshmi (2001) concluded that India has taken several measures 'including legislation to ensure the full development and advancement of women, for the purpose of guarantying them the exercise and enjoyment of human rights and fundamental freedoms on the basis of equality with men'.

The members were aware about political institutions but contesting in election was found to be low priority area though they had participated in electoral process. The other reason might be that as majority of the members were under marginal, small and landless; it didn't encourage them to participate in political activities as the foremost important to them was to be economically empowered.

\section{Legal empowerment}

A look at table 1 revealed that $45.42,30.83$ and 23.75 per cent of the respondents had low, medium and high levels of legal empowerment, respectively. It can be inferred that majority of the respondents had low level of legal empowerment. It can be attributed to the restrictive social norms, complexity of legal process and utmost affinity of women towards their family which limit them to adopt legal course of action for settlement of family disputes.

\section{Technological empowerment}

As far as technological empowerment level was concerned, it was found that more than half $(55.00 \%)$ of the respondents had medium level of technological empowerment while nearly one-fourth $(24.58 \%)$ of the respondents had low and 20.42 per cent of them could make to the high level of technological empowerment. The results are in line with the findings of Pandey (2005) and Kumari (2008). Bulatao et al., (1993) revealed that in Philippines women as dairy managers and women technicians were proving to be of considerable assistance to the cooperatives. Women involved in dairying were found to make strenuous efforts to maximize the resources within their reach despite difficulties faced.

The result indicated that women had medium level of technological knowledge related to dairying due to the role of co-operatives played in organizing training, demonstrations, etc. which tended to promote technology acquisition behaviour among the women. Members were aware about clean milk production practices, machine milking, timely vaccination, de-worming, use of artificial insemination for animals and knowledge about SNF and fat estimation test. Further, it was noticed that nearly 80 per cent of the members were having either medium or low level of technological empowerment. This situation needs to be improved for better dairy development as well as for all round development of the rural masses especially, the women.

\section{Level of the empowerment under different dimensions}

To know the level of empowerment, an index value of the women empowerment was calculated for each dimension of Dairy Women Empowerment Index (DWEI) which consists of number of statements and hence, their range of total scores was different. Therefore, the total score of each dimension was converted into unit score by using simple range and variance as given below: 
$\mathrm{Uij}=\frac{\mathrm{Yij}_{\mathrm{ij}}-\mathrm{Min} \mathrm{Yij}_{\mathrm{ij}}}{\operatorname{Max} \mathrm{Yj}-\mathrm{Min} \mathrm{Y}_{\mathrm{j}}}$

where,

$\mathrm{U}_{\mathrm{ij}}=$ Unit score of the $\mathrm{i}^{\text {th }}$ respondents on $\mathrm{j}^{\text {th }}$ dimension

$Y_{i j}=$ Value of the $i^{\text {th }}$ respondent on the $j^{\text {th }}$ dimension

Max $Y_{j}=$ Maximum score on the $j^{\text {th }}$ dimension

Min $Y_{j}=$ Minimum score on the $j^{\text {th }}$ dimension

Thus, the score of each dimension range from 0 to 1 i.e. when Yij is minimum, the score is 0 and when Yij is maximum the score is 1 . Then the unit scores of each respondent was multiplied by respective scale value of each dimension and summed up. Thus, the obtained score was divided by the sum of scale values in order to get the DWEI for each respondent.

$D W E I i=\frac{\sum \mathrm{Uij} * \mathrm{Sj}}{\text { Sum of scale values }}$

Where,

DWEI $_{i}=$ Dairy Women Empowerment Index of $i^{\text {th }}$ respondent

$\mathrm{U}_{\mathrm{ij}}=$ Unit score of the ith respondent on $\mathrm{jth}$ component

$\mathrm{Sj}=$ Scale value of the jth component

$\sum=$ Sum

The status of respondents' empowerment was calculated based on the total index score of all the indicators.

The table 2 enunciates the index value of women empowerment and its dimensions achieved through activities carried out by women dairy cooperatives (WDCs) for empowering women. Overall empowerment index of dairy women was found to be 0.64 which indicates that there empowerment level was found to be the 64 per cent achieved through the activities of WDCs. In field studies cent per cent result can't be achieved at once compared to the laboratory experiments as real subjects are involved with many uncontrolled external variable factors influencing them and in the social field study it may take decades to achieve the desired result, even though 64 per cent is also an encouraging figure.

From table 2, it could be observe amongst the different dimensions of women' empowerment, psychological was 0.75 (75 per cent) which was found to be the highest. It stands as a fundamental step for achieving empowerment under other dimensions. It is followed by social empowerment (0.74 index value), economic empowerment (0.68 index value), legal empowerment (0.63 index value), cultural empowerment (0.61 index value), technological empowerment (0.59 index value) and political empowerment (0.50 index value).

Through Dairy Women Empowerment Index (DWEI), we were able to find that psychological empowerment plays a key role in empowering women. Once the women are psychologically empowered then in next stages it leads to empowerment in other different dimensions of empowerment. This should be taken care in other development programmes also. More emphasis has to be given on economic empowerment by training them on other income generating activities like training to members on value addition for sustaining the WDCs. WDCs should also work to enhance political and legal empowerment through awareness campaign however; they should be motivated to maintain the cordial environment in the family. Since technological empowerment was assigned $6^{\text {th }}$ rank, WDCs are required to pay much attention towards this dimension as productivity, production and income depend 
on it. Empowerment on it can be achieved through, skill oriented trainings, kisan melas, gosthis, tours, demonstrations, community radio and TV. Further, the linkage with other concerned departments may also be improved to take benefits of their relevant programmes for capacity buildings of the members.

\section{Correlation between profile variables and women empowerment}

Correlation coefficient is a measure of the relationship between two variables which are at the interval or ratio level of measurement and are linearly related. The range of correlation coefficient is between -1 to +1 . This means that -1 is perfect negative correlation, +1 is perfect positive correlation. Correlations express the association between variables. From table 3, it can be enunciated that herd size, milk production, milk sale, income from dairying, social participation, training received and information seeking behaviour are positively and highly significantly correlated while education, land holding as well as total annual income are positively and significantly correlated with dairy women empowerment. Age and family size were found to be not correlated with the dairy women empowerment.

\section{Age and empowerment}

Age has non-significant relationship with empowerment. It can be depicted that age of the women was not contributing towards empowerment which implies empowerment can occur irrespective of age. It may be due to that every human being whatever his/her age may be, has an urge to be respected in the society which is also true in case of women.

\section{Education and empowerment}

Education is positively significant with empowerment at five per cent level of significance. Women are more likely to control their own destinies and effect change in their own communities when they have higher levels of education. Education is often seen as one of the main pathways to achieve another key development goal for women's empowerment. Education is one of the most important means of empowering women with the knowledge, skills and self-confidence necessary to participate fully in the development process.

Education as means of empowerment of women can bring about a positive attitudinal change. It is therefore, crucial for the socioeconomic and political progress of India. The Constitution of India empowers the State to adopt affirmative measures for prompting ways and means to empower women. Education significantly makes differences in the lives of women. These can be direct or indirect.

\section{Family size and empowerment}

Family size is having non- significant relationship with empowerment. It might be due to that attitude of the self, society and family members does matter more for empowerment of women rather than the family size.

\section{Land holdings and empowerment}

Land holdings are positively and significantly correlated with women empowerment at five per cent level of probability. It can be articulated that increase in acerage increases women empowerment level accordingly. This might be due to the fact that individuals with more land holding might have better income, socio-economic status, opportunity for formal education, exposure to mass media leading to acquisition of knowledge and skill involved in different income generating activities, which will encourage saving habits and control of the money earned by them. 


\section{Herd size and empowerment}

Herd size is positively and highly significantly correlated with empowerment of dairy women which shows that it plays a core role in empowering women economically and socially.

Increase in number of animals resulted in increase of income accordingly it helped in psychologically boosting their morale. As the village women became the members of WDCs, they were provided with loan to purchase crossbred cows which acted as a gizmo to increase their assets.

\section{Milk production and empowerment}

Milk production was found to be correlated with dairy women empowerment positively at one per cent level of probability. The production echelon of milk was comparatively good in the study area as most of the members were rearing crossbred cows which are highly productive.

\section{Milk consumption and empowerment}

Milk consumption is positively significant at five per cent level of probability with empowerment. As milk production was found to be high among the members, due to which they could use more milk for their consumption which increased their nutritional security.

\section{Milk sale and empowerment}

Milk sale had highly positive and significant association with dairy women empowerment. As already stated, milk production was more accordingly milk sale was also more. In addition, assured market located near the vicinity of village for milk sale could generate regular income resulted in more empowerment of women.

\section{Income from dairying and empowerment}

Income from dairying was found to have significant association with dairy women empowerment at one per cent level of probability. Unusual from crop farming, dairying is a source of regular cash inflow, received daily, weekly or at least fortnightly. Women were able to make savings, mostly through women self-help groups.

Respondents further used the income from dairying for crop production, marriage functions, to pay back loan, meet out personal expenses, etc which empowered them economically.

\section{Total annual income and empowerment}

Total annual income is significantly and positively correlated with empowerment of women at five per cent level of significance. Food, educational, social security, etc. depends on the earnings of the person which directly affecting the empowerment positively.

\section{Social participation and empowerment}

Social participation had positive and highly significant correlation with empowerment of women. Being the members of WDCs it helped them to be active socially in different social organizations which increased mobility of the members constantly heading towards empowering 'she'.

\section{Training received and empowerment}

Training received was found to be positively and highly significantly correlated with empowerment of women. Trainings on various aspects, increased their knowledge, skill, attitude, exposure and experience thus, helped in capacity building of women. Further, all the trainings were free of cost which encouraged more participation; finally 
it leads towards the empowerment of dairy women members of WDCs.

Information seeking behaviour and empowerment

Information seeking behaviour had highly significant positive relation with empowerment of women. Different activities carried out by the WDCs created hunger of information among the members for their empowerment. Due to social participation and trainings attended, it obviously leads to the urge for seeking more information about ongoing issues leading to an overall empowerment of women.

\section{Multiple regressions between profile} variables and women empowerment

Most commonly, regression analysis estimates the conditional expectation of the dependent variable given the independent variables - that is, the average value of the dependent variable when the independent variables are constant.

The multiple regression analysis was carried out to assess the extent of influence of independent variables towards the dairy women empowerment.

From table 4, it can be observed that coefficient of multiple determinations $\left(R^{2}\right)$ was 0.517 which means that 51.70 per cent of variation in dependent variable is explained by independent variables.

The value of adjusted $R^{2}$ is 0.492 which implies that if the model is estimated from the population rather than the sample it would account for approximately 2.50 per cent $(0.517-0.492)$ less variance in outcome. The F-value of 20.84 signifies that the fitted model is statistically significant at 0.01 level of probability.
Unit increase in social participation, training received and information seeking behaviour, ceteris paribus, would result in increasing the dairy women empowerment to an extent of $0.004,0.007$ and 0.002, respectively. Social participation, training received and information seeking behaviour had positive and significant contribution towards dairy women empowerment. This might be due to social participation, training received and information seeking behavior facilitated women to acquire knowledge, enhanced their mobility in the social system and made them capable to harness the benefits associated with dairying.

Step-wise regression analysis between profile variables and women empowerment

Step-wise regression analysis was done to eliminate such of those independent variables whose contribution to dependent variable was considered to be minimum. It explains the contribution of added or deleted variables in explaining dependent variables (by seeing the change in $R^{2}$ value). The results of the stepwise regression analysis of independent variables towards dairy women empowerment are presented in table 5 .

It indicates that due to considerable colinearity between explanatory variables, only three independent variables namely social participation, training received and information seeking behaviour, were found significant at 0.01 level of probability. The contribution of training received was found to be highest with 50.30 per cent $\left(R^{2}=0.503\right)$, followed by 45.30 per cent $\left(R^{2}=0.453\right)$ and 31.60 per cent $\left(\mathrm{R}^{2}=0.316\right)$ of contribution by information seeking behaviour and social participation, respectively.

It was also revealed that a unit increase in training received ceteris paribus would result in increase of dairy women empowerment to a 
tune of 0.237 unit while with regard to information seeking behaviour ceteris paribus, would result in increase of 0.340 unit and for social participation ceteris paribus, would result in increase of 0.397 unit.

Table.1 Distribution of the respondents according to different dimensions of empowerment $\mathrm{n}=240$

\begin{tabular}{|c|c|c|c|}
\hline $\begin{array}{l}\text { Sl. } \\
\text { No. }\end{array}$ & Dimensions & Frequency & Percentage \\
\hline \multirow{4}{*}{1.} & Social Empowerment & & \\
\hline & Low (up to 0.68 ) & 83 & 34.58 \\
\hline & Medium $(0.69-0.79)$ & 90 & 37.50 \\
\hline & High (above 0.79) & 67 & 27.92 \\
\hline \multirow{4}{*}{2.} & Cultural Empowerment & & \\
\hline & Low (up to 0.49 ) & 40 & 16.67 \\
\hline & Medium $(0.50-0.79)$ & 114 & 47.50 \\
\hline & High (above 0.79) & 86 & 35.83 \\
\hline \multirow{4}{*}{3.} & Psychological Empowerment & & \\
\hline & Low( upto 0.65 ) & 50 & 20.83 \\
\hline & Medium $(0.66-0.80)$ & 102 & 42.50 \\
\hline & High (above 0.80 ) & 88 & 36.67 \\
\hline \multirow{4}{*}{4.} & Economic Empowerment & & \\
\hline & Low (up to 0.53 ) & 48 & 20.00 \\
\hline & Medium $(0.54-0.76)$ & 106 & 44.17 \\
\hline & High (above 0.76 ) & 86 & 35.83 \\
\hline \multirow{4}{*}{5.} & Political Empowerment & & \\
\hline & Low(up to 0.40 ) & 102 & 42.50 \\
\hline & Medium(0.41 - 0.63) & 85 & 35.42 \\
\hline & High(above 0.63 ) & 53 & 22.08 \\
\hline \multirow{4}{*}{6.} & Legal Empowerment & & \\
\hline & Low (up to 0.57 ) & 109 & 45.42 \\
\hline & Medium $(0.58-0.71)$ & 74 & 30.83 \\
\hline & High (above 0.71) & 57 & 23.75 \\
\hline \multirow{4}{*}{7.} & Technological Empowerment & & \\
\hline & Low (upto 0.54) & 59 & 24.58 \\
\hline & Medium $(0.55-0.65)$ & 132 & 55.00 \\
\hline & High (above 0.65 ) & 49 & 20.42 \\
\hline \multirow{4}{*}{8.} & Overall Empowerment & & \\
\hline & Low (upto 0.58) & 87 & 36.25 \\
\hline & Medium (0.59-0.68) & 104 & 43.33 \\
\hline & High (above 0.68 ) & 49 & 20.42 \\
\hline
\end{tabular}


Table.2 Level of the empowerment under different dimensions

\begin{tabular}{|r|l|c|c|}
\hline \multicolumn{1}{|c|}{ SI } & \multicolumn{1}{|c|}{$\begin{array}{c}\text { Seven Dimensions of Dairy Women } \\
\text { Empowerment Index }\end{array}$} & Index Value & Rank \\
\hline 1. & Social Empowerment & 0.74 & II \\
\hline 2. & Cultural Empowerment & 0.61 & V \\
\hline 3. & Psychological Empowerment & 0.75 & I \\
\hline 4. & Economic Empowerment & 0.68 & III \\
\hline 5. & Political Empowerment & 0.50 & VI \\
\hline 6. & Technological Empowerment & 0.59 & IV \\
\hline 7. & Legal Empowerment & & 0.63 \\
\hline \multicolumn{2}{|c|}{ Overall empowerment Index } \\
\hline
\end{tabular}

Table.3 Correlation between profile variables and women empowerment

\begin{tabular}{|l|l|l|}
\hline Sl. No. & Profile variables & Co-efficient of correlation (r) \\
\hline 1 & Age & 0.015 \\
\hline 2 & Education & $0.147^{*}$ \\
\hline 3 & Family Size & 0.058 \\
\hline 4 & Land Holdings & $0.144^{*}$ \\
\hline 5 & Herd Size & $0.185^{* *}$ \\
\hline 6 & Milk Production & $0.175^{* *}$ \\
\hline 7 & Milk Consumption & $0.132^{*}$ \\
\hline 8 & Milk Sale & $0.171^{* *}$ \\
\hline 9 & Income from Dairying & $0.176^{* *}$ \\
\hline 10 & Total Annual Income & $0.164^{*}$ \\
\hline 11 & Social Participation & $0.563^{*}$ \\
\hline 12 & Training Received & $0.431^{* *}$ \\
\hline 13 & Information Seeking Behaviour & $0.523^{* *}$ \\
\hline \multicolumn{2}{|c|}{$*$ - Significant at 5 per cent level of significance } \\
\multicolumn{2}{|c|}{$* *$ - Significant at1 per cent level of significance }
\end{tabular}

Table.4 Multiple regression between profile variables and women empowerment

\begin{tabular}{|c|l|c|c|c|}
\hline Sl. No. & \multicolumn{1}{|c|}{ Variables } & Co-efficient & Standard Error & t-value \\
\hline $\mathbf{1}$ & Age & 0.048 & 0.001 & 1.030 \\
\hline $\mathbf{2}$ & Education & 0.087 & 0.004 & 1.717 \\
\hline $\mathbf{3}$ & Family Size & 0.036 & 0.002 & 0.738 \\
\hline $\mathbf{4}$ & Land Holdings & 0.005 & 0.006 & 0.681 \\
\hline $\mathbf{5}$ & Herd Size & -0.012 & 0.006 & -0.154 \\
\hline $\mathbf{6}$ & Milk Consumption & -0.036 & 0.007 & -0.600 \\
\hline $\mathbf{7}$ & Milk Sale & -0.284 & 0.004 & -1.063 \\
\hline $\mathbf{8}$ & Income from Dairying & 0.376 & 0.000 & 1.360 \\
\hline $\mathbf{9}$ & Total Annual Income & -0.081 & 0.000 & -0.861 \\
\hline $\mathbf{1 0}$ & Social Participation & 0.396 & $0.004^{* *}$ & 7.683 \\
\hline $\mathbf{1 1}$ & Training Received & 0.230 & $0.007^{* *}$ & 4.675 \\
\hline $\mathbf{1 2}$ & Information Seeking Behaviour & 0.334 & $0.002^{* *}$ & 6.689 \\
\hline & \multicolumn{3}{|l}{} \\
\hline
\end{tabular}


Table.5 Step-wise regression analysis between profile variables and women empowerment

\begin{tabular}{|c|c|c|c|c|c|}
\hline $\begin{array}{c}\text { Sl. } \\
\text { No. }\end{array}$ & Variables & Co-efficient & Standard Error & t-value & $\mathbf{R}^{2}$ change \\
\hline $\mathbf{1}$ & Social Participation & 0.397 & $0.003^{* *}$ & 8.067 & 0.316 \\
\hline $\mathbf{2}$ & Training Received & 0.237 & $0.033^{* *}$ & 4.883 & 0.503 \\
\hline $\mathbf{3}$ & $\begin{array}{c}\text { Information Seeking } \\
\text { Behaviour }\end{array}$ & 0.340 & $0.007^{* *}$ & 6.907 & 0.453 \\
\hline
\end{tabular}

It can be concluded that social participation, training received and information seeking behaviour were playing a major role in empowering the women. There by, it is suggested that these variables should be taken care of while devising policies and programmes for women empowerment.

In conclusion, WDCs not only play a core role in empowering rural women but also form a hub of platform to the weaker sections of them to put forth their genuine problems. More emphasis has to be given on economic empowerment by training them on other income generating activities like value addition for sustaining the WDCs. It is suggested that WDCs should encourage women to take part in political activities also. The role played by WDC is much appreciated which can also be replicated in other parts of the country. For greater acceleration rate of empowerment, future strategy must focus more and more on training and capacity building of members besides ensuring adequate linkage support.

\section{References}

Anonymous. 2010-11. Report of Food and Agriculture Organization (FAO) on women in agriculture: Closing the gender gap for development.

Anonymous. 2012. Report of World Bank on gender equality and development.

Anonymous. 2013-14. Annual Report, Department of Animal Husbandry, Dairying and Fisheries, Ministry of Agriculture, Government of India, New
Delhi.

Anonymous. 2014. Report of Food and Agriculture Organisation on Livestock Group, milk production, domain, etc. in Indian perspective Retrieved from: http://faostat3.fao.org/faostat-gateway/ go/to/compare/Q/QC/E on 8.7.2015.

Anuradha. 2004. Empowerment of rural women under SWA - Shakthi project through self help groups. M.Sc. Thesis. Unpub.), CCS Haryana Agriculture University, Hisar.

Bagyalakshmi, J. 2001. Human Rights and Freedom. Yojana, 14(2): 15-16.

Belurkar, G.M., Wakle, P.K. and Gholve, M.A. 2003. A study on decision making pattern and participation of rural women in animal husbandry and dairying enterprise. Maharashtra J. Extension Education, 22(2): 81-85.

Bulato, S., Bayley, J.E., Paranell, E. and Hurup, W. 1993. Women in the Philippine's dairy cooperatives. Plunkelt Foundations for Cooperative studies, Long Hanborough, Oxon, U.K. Yearbook of Cooperative Enterprise: 165-172.

Census. 2011. Census Report, Office of the Registrar General and Census Commissioner, Ministry of Home Affairs, Government of India.

Chandrashekar, E. 2013. Local governance and empowerment of elected women- A case study of south Karnataka. Asian J. Res. Social Sci. Humanities, 3(6): 2141.

Chayal, K., Daaka, B.L., and Suwalka, R.L. 2009. Analysis of role performed by 
farm women in dairy farming. Indian $J$. Dairy Sci., 62: 491-494.

Datta, P.B. and Gailey, R. 2012. Empowering women through social entrepreneurship: Case study of a women's cooperative in India. Entrepreneurship Theory and Practice.

Fulzele, R.M. and Meena, B.L. 1995. Training needs of dairy tribal women. Indian J. Dairy Sci., 48: 551-553.

Garai, S., Mazumder, G. and Maiti, S. 2012. Empowerment of women through self help groups approach: Empirical evidence from West Bengal, India. African J. Agri. Res., 7(48): 6395-6400.

John CR and Thirunavukkarasu M. 2002. Role of farm women in livestock keeping. Indian Dairyman, 54: 35-40.

Joshi, M. 2004. Empowerment of rural women cynosure of future. Kisan World, 7: 15-16.

Kishor, S. and Gupta, K. 2009. Gender equality and women's empowerment in India. National Family Health Survey India. Ministry of Health and Family
Welfare, Government of India, New Delhi.

Kumari, P. 2008. Gender analysis of dairy cooperatives in Harayana. Ph.D. Thesis. Unpub.), National Dairy Research Institute, Karnal, Haryana.

Lahoti, S.R., Chole, S.R. and Rathi, N.S. 2012. Role of women in dairy farming. Indian J. Dairy Sci., 65(5): 442-446.

Pandey, R. 2005. Empowerment of women through women dairy cooperatives. Ph.D. Thesis. Unpub.), National Dairy Research Institute, Karnal, Haryana.

Putnam, R.D. 2000. Bowling Alone: The Collapse and Revival of American Community. New York: Simon and Schuster: 541.

Sheela, K.S. and Ramegowda, A. 2013. Dairy cooperatives and empowerment of women. Int. J. Adv. Social Sci. Humanities, 2(9): 34-42.

Simiyon, S., Saravanan, S. and Suresh. 2013. Women Empowerment through Self Help Groups: A Case Study, Economic Affairs, 58(2): 147-154.

\section{How to cite this article:}

Niketha, L., Gopal Sankhala, Kamta Prasad and Sanjeev Kumar. 2017. Empowerment of Women through Dairy Cooperatives in Karnataka. Int.J.Curr.Microbiol.App.Sci. 6(7): 12921304. doi: https://doi.org/10.20546/ijcmas.2017.607.156 